\section{Reactor plans drawn up}

\section{Munich}

NuClear fusion scientists from the Soviet Union, Europe, Japan and the United States, meeting in Vienna, have come up with an approximate construction schedule and a cost for the International Thermonuclear Experimental Reactor (ITER), a machine intended to assess the engineering requirements of a full-scale fusion reactor. The estimated cost of building ITER is $\$ 4,900$ million, but for now the fusion community is asking the collaborating governments only for money to begin the design phase.

Exploratory planning has been going on since 1988 at Garching, West Germany, near the Max Planck Institute for Plasma Physics, and should be complete by the end of this year. According to the ITER council, which is administered by the International Atomic Energy Agency in Vienna, a detailed design could be ready by 1995 , and the reactor itself would then take another six years to build. Although ITER is not expected to generate more energy than it consumes, it should demonstrate the feasibility of holding a burning plasma for a long enough time and in the quantity that a commercial reactor would need.

The final decision on whether to build ITER, which can come only after details of cost-sharing have been worked out and an acceptable site found, is not likely to be made before 1993. In the meantime there seems to be general enthusiasm for the engineering design phase. Europe would agree to begin the next phase, predicted West German fusion expert Siegfried von Krosigk of the Research Ministry. ITER would overlap by "98 per cent" with the Next European Torus (NET) that Europe is planning, he said, so collaboration would save money.

Von Krosigk said that the Soviet Union has "generally been very positive" in its attitude towards ITER. Japan is also likely to go along with ITER, hinted Ken Tomabechi, chairman of the ITER management committee. "I have heard nothing negative", he said.

The US fusion programme has still not recovered from the upsets of last year, when efforts were made to stall research into magnetic fusion to allow work on laser confinement fusion to catch up (see Nature 341, 476; 1989). The 1991 budget (see page 397 ) provides continued support for ITER, but does not provide money to begin building the next domestic reactor, the Compact Ignition Tokamak (CIT). If the political budget battles turn into a contest between ITER and CIT, money for both projects will become volatile.

Steven Dickman

\title{
Spaceport under a cloud
}

\section{Sydney}

US fears that the United States may lose technical information to the Soviets could put a stop to Australia's plans to build a 'spaceport' offering commercial launch services at Temple Bay on Cape York peninsula in far north Queensland.

The Australian plan calls for Sovietmade rockets to be used to launch satellites manufactured in the United States and other countries. The United States is likely to object on security grounds.

The Commonwealth government has endorsed the proposal by the Cape York Space Agency (CYSA) to build the facility, and negotiations to buy Soviet rockets, which are much cheaper than their US equivalents, have already been under way for two years. But in the second half of 1989 , several pieces of legislation were put to the US Congress that could hinder the use of the Cape York facility by US manufacturers of satellites, according to Bruce Middleton, executive director of the Australian space office.

Only one of the bills has so far been enacted into law. An amendment to the Appropriation Bill for the Departments of Commerce, Justice and State, it prohibits the granting of export licences for the launch of US satellites on Soviet or Chinese rockets. The amendment is active only until October 1990.

A clause in the amendment provides US President George Bush with the power to lift the ban if it is in the national interest.

Last December, Bush used this clause to reinstate export licences, revoked in the wake of the Tiananman Square massacre for two US-manufactured satellites purchased by Aussat Pty Ltd, an Australian company. They will be launched from a Chinese Long March Rocket in 1991.

Other legislation includes two amendments to the NASA Authorisation Bill. One prohibits the export of US-built satellites to other nations for launch on rockets from the Soviet Union. The other prohibits the use of Soviet rockets except in circumstances where the president certifies to Congress that the price of the Soviet launch "is not more than 25 per cent below the price of a comparable launch vehicle built in a market-based economy". Middleton says that the US legislation is being taken seriously in Australia, but "it is not an insurmountable obstacle and is capable of change". There are also problems back home. On 2 December, Queensland elected a Labor government which will back a study of the impact of the spaceport on the environment and on aboriginal heritage land. The proposed site, is considered traditional land by the Wuthathi Aboriginal Council.

The spaceport is to be a fully commercial venture but the Commonwealth support for the venture necessary to entice investors is conditional upon the satisfactory completion of environmental studies. "If at the end of the environmental impact study phase the Commonwealth and the State indicate that they are not in favour of the project then we will not proceed", says CYSA director Stephen Williams.

Tania Ewing

\section{Successful launch for Spot-2 shop-window}

\section{Paris}

AFTER a series of setbacks over the past several weeks, the French commercial remote-sensing satellite, Spot-2, was launched successfully by an Ariane 40 rocket on the night of 21 January. Accompanying Spot-2 into space was a payload of 'auxiliary passengers' - six microsatellites for British and US customers.

Spot-2 was built by the French company Matra for the state space research centre (CNES) and will enable its twin, Spot-1, to be retired at last. Spot-1 was launched in February 1986 with a planned lifetime of two years. Its continued operation, despite a failed tape recorder on board, has meant that CNES has been able to recoup development costs faster than expected.

But Spot Image SA, the company created by CNES to sell Spot pictures, is still far from making a profit. Last year, the company's turnover was FF130 million, while, in 1988, overheads were running at FF210 million. And Spot-2 is estimated to have cost FF500 million to build.

Nevertheless, Spot is a good shopwindow for French space technology. Next will come Spot-3, due for launch at the end of 1992. Last July, Prime Minister Michel Rocard gave the go-ahead to build Spot-4.

The Ariane launch also put six microsatellites into low orbit. Two of them (UOSAT D and E), weighing less than $50 \mathrm{~kg}$, will be used to 'store and forward' messages from their owners, the University of Surrey in Britain, and more than 200 British schools and universities. The other four satellites each weigh only $12 \mathbf{~ k g}$ and belong to the US amateur radio satellite corporation, AMSAT. They will be used for communications, education and colour photography using a charge-coupled device camera.

Although microsatellites are still uncommon in the West, the Soviet Union has been launching its Kosmos satellites, weighing 40-50 kg, since 1964 .

Peter Coles 